\title{
1. The UN Security Council and global action on climate change
}

\author{
Shirley V. Scott and Charlotte Ku
}

\section{INTRODUCTION}

Climate change has long been recognized as constituting a threat to international security. The 1988 Toronto Conference, which marked the beginning of intergovernmental cooperation on climate change,${ }^{1}$ acknowledged in its conference statement that changes to the earth's atmosphere 'represent a major threat to international security'. ${ }^{2}$ More recently, research has pointed both to the threat posed directly by extreme storms, drought, rising sea levels and floods but also by indirect impacts, such as those on human health, displacement and migration, and conflict. ${ }^{3}$ In each of these scenarios, climate change serves as an 'underlying metadriver of unpredictable instability'. ${ }^{4}$ To date, however, even discussion of the climate issue by the United Nations Security Council has been contentious.

Global governance responses to climate change remain centred on the United Nations Framework Convention on Climate Change (UNFCCC) regime, emanating from the UN General Assembly. In the same year that the Toronto Conference declared climate change a threat to international security, the United Nations General Assembly (UNGA) declared climate change to be a 'common concern of mankind', ${ }^{5}$ setting in place a tension that has existed ever since - between the UN Security Council as the apex of the international security institutional architecture and the UNFCCC regime founded on the principle of 'Common But Differentiated Responsibilities' (CBDR). Many still espouse the view that the Council lacks the legitimacy to take action in the climate change policy arena.

The complex nature of the climate change governance challenge means, however, that the issue and/or its consequences now also feature on the agenda of an ever-increasing array of international institutions, including the G20, International Maritime Organization, World Bank and 
the Office of the United Nations High Commissioner for Refugees. There has been growing recognition of the need for far-reaching, complementary efforts requiring enhanced coordination on the part of all international institutions; the most recent report of the Intergovernmental Panel on Climate Change (IPCC) pointed to the need in climate change governance to 'maximise potential institutional synergies' ${ }^{6}$

The need for institutional coordination is set to increase. Relevant recent advances in climate science point to the possibility of reaching future social and political tipping points that would constitute multifaceted and multiscalar global crises. Absent dramatically greater policy success than hitherto, the question of whether it would be legitimate for the Council to respond to climate change might well be reversed at such a point to the question of how the Council could legitimately and realistically refuse to contribute to governance solutions. This makes it particularly apposite to consider what constructive steps the Council could take to better prepare for the possibility of at some point needing to assume the role of global crisis coordinating body responding to the direct and indirect consequences of a warming planet.

This volume seeks to contribute to just such a discussion. This chapter first traces the evolution of the United Nations Security Council (UNSC) to demonstrate that there is a history of the Council tackling new dimensions of international security and developing new tools and processes with which to do so. The chapter then investigates the historical evolution of consideration of climate change by the Council and the gradual shift that has taken place from the issue of whether the Council has any legitimate role to play, to that of how best the Council might make a contribution and, how best it might relate its efforts to those being taken by other international, and indeed national and local, actors. This chapter lays the groundwork for the more detailed consideration of specific Council tools in subsequent chapters.

\section{THE EVOLVING SECURITY COUNCIL}

The United Nations Security Council is not a complete stranger to the issue of climate change. The Council debated the question in 2007, and in 2012 the Council issued a presidential statement on the security implications of climate change. In passing a resolution on the conflictaffected populations of the Lake Chad Basin, the Council in 2017 recognized that climate change had had adverse effects on the stability of the region. ${ }^{7}$ To date, however, the Council has taken no decision with climate change per se as its primary focus. This does not mean that it 
could not or should not do so. Any consideration of a potential role for the United Nations Security Council in responding to climate change must start with an appreciation of the fact that the Council has by no means been a static institution. This section will therefore briefly review the structure of the Council as well as its evolution to date.

Article 24 of the United Nations Charter gives the UNSC 'primary responsibility for the maintenance of international peace and security'. The Security Council was created by the UN's founders to be a flexible body prepared to address issues that might pose threats to large numbers of people, to destabilize international order, or to threaten the survival and vital interests of states. As Edward Luck wrote, 'They were much less interested in conceptions of warfare than in who would make the critical decisions. Moreover, on the issue of decision-making, their priorities were performance, unity, and control, not equity' ${ }^{8}$ This led to a UNSC power structure, as established by the Charter, rooted in the role of the P5 members (China, France, Russia, the United States and the United Kingdom) and their substantive veto.

Decisions of the Security Council bind all UN members and it acts on behalf of the entire UN membership even though its membership is limited to 15 (Article 48). Five of these 15 are the 'P5', permanent members who do not rotate off the Council and that each have the right, on some decisions, to cast a veto that can block UNSC action. Substantive decisions of the Council require a majority of nine, inclusive of P5 concurrence or abstention (Article 27). The other ten members are elected by the General Assembly for two-year terms (Article 23).

The oligarchic UNSC was designed to provide for speedier decisionmaking and greater capacity to respond to crises and emergencies than had the League of Nations, which had required unanimity for its Council to act. Article 28 of the Charter provides that: 'The Security Council shall be so organized as to be able to function continuously'. Together with the UN Secretary-General, the UNSC in continuous session is the organ that provides ongoing oversight, management and coordination of UN activities. The structures and procedures of the UNSC are also a way for its permanent members to make sure they can control decisions on matters affecting their individual interests, so reducing the possibility of tension amongst members of the P5.

The post-World War II world into which the UN Security Council was launched in 1945 demanded that the Council adapt from the moment of its birth. The UNSC was originally designed to be an operational body with national military forces at its disposal (Articles 43 and 45) and a Military Staff Committee composed of the P5 chiefs of staff (Article 47) 'to advise and assist the Security Council on all questions relating to the 
Security Council's military requirements for the maintenance of peace and security, the employment and command of forces placed at its disposal, the regulation of armaments, and possible disarmament'. With the advent of the Cold War, no agreement could be reached on the earmarking of national forces by the P5 or on establishment of the Military Staff Committee. This meant that the major means envisioned by the Charter to enable the UNSC to implement its decisions were not available. Nor could a consensus be reached on what constituted a 'threat to the peace, breach of the peace, or act of aggression' under Article 39.

When the UN was founded in 1945, there were 51 members; today, there are 193. Many of these states emerged from colonial rule with religiously and ethnically diverse populations, inadequate government institutions, and contested borders that have given rise to intrastate conflict. Interstate war declined after 1945, but conflict internal to a state increased, with one study showing a breakdown of 11 per cent interstate and 89 per cent intrastate wars for the period 1980-97. ${ }^{9}$ While the General Assembly often dealt with such issues before 1990, the end of the Cold War, the collapse of the Soviet Union and the destruction of Yugoslavia a quarter-century ago brought the UN a score of new members and put 'ethnic cleansing' and civil war on the agenda of the Security Council. Since the turn of the twenty-first century, that agenda has also included terrorism by non-state actors.

Despite the rise in intrastate conflict, interstate conflict and crossborder aggression have not been eliminated. The UNSC has authorized combat operations that have been carried out by states capable of deploying and sustaining combat forces and of commanding and controlling them. In these cases, multinational forces have operated under a 'lead nation', the aegis of another international organization, or parallel national commands. Examples of such operations are:

- US-led combat operations against North Korea (1950-53);

- US-Gulf Cooperation Council-led operation to liberate Kuwait (1990-91);

- US-Gulf Cooperation Council US-led intervention in Somalia Unified Task Force in Somalia (1992-93) and the French-led Operation Turquoise in 1994;

- NATO-led Implementation Force (IFOR, 1995-96) and Stabilization Force (SFOR, 1996-2004) in Bosnia, and Kosovo Force (KFOR, 1999-present). ${ }^{10}$

To deal with both interstate and intrastate conflicts, one of the UN's major innovations has been multinational peacekeeping operations 
(PKOs). Although not envisioned in the Charter, by the early 1960s UN peacekeeping personnel wearing blue helmets had become one of the most visible and recognizable symbols of the organization. The General Assembly created the first PKO, the United Nations Emergency Force (UNEF), as a response to the 1956 Suez crisis. UNEF established a buffer zone around the Suez Canal and in Gaza and the Sinai that allowed the withdrawal of British, French, and Israeli forces from the area. Its mandate required it to report to the Security Council.

Sixty years later, in 2016, the UNSC was overseeing 16 PKOs involving over 89000 troops, more than 12000 police, and 1800 military observers, in addition to more than 16000 civilian personnel, at an annual cost of just over $\$ 8$ billion. ${ }^{11}$ Financial contributions for peacekeeping operations are made separately based on a special assessment rate established by UN members. The top ten financial contributors to UN peacekeeping are: the United States (28.38 per cent), Japan (10.83 per cent), France (7.22 per cent), Germany (7.14 per cent), United Kingdom (6.68 per cent), China (6.64 per cent), Italy (4.45 per cent), Russian Federation (3.15 per cent), Canada (2.98 per cent), and Spain (2.97 per cent). ${ }^{12}$

The changing nature of conflict is reflected in the changing nature of UN missions. There was once a strong presumption that states had to consent to the deployment on their territory of UN PKOs, but after 1990 UN mandates became more interventionist and deployed forces were sometimes directed to act against the government in whose territory the missions operated. With the end of the Cold War and following the 1992 Security Council summit where member state heads of government met to consider the feasibility of returning the UNSC to its central role in maintaining peace and security, there was a sharp increase in both the number and complexity of PKOs.

Of the 71 peacekeeping operations from 1956 to 2015, only 20 were undertaken before 1990, and of those 20 only six were what we would today call complex peacekeeping that included state building and enforcement mandates. ${ }^{13}$ This compares to the more than 50 missions since 1990 charged with responsibilities to implement tasks such as organizing and holding elections, repatriation of displaced persons and refugees, compliance with human rights obligations, demobilization of military forces, and creation of secure conditions for the delivery of humanitarian assistance. ${ }^{14}$

A comparison of the first ten years (1945-55) of UNSC reports to the UN General Assembly and the more recent ten years (2005-15) further shows the change in the UNSC's scope of responsibility. In the first ten years, the Council carried out its Charter-mandated duties dealing with 
the appointment of the UN Secretary-General, admission of new members, and the election of judges to the International Court of Justice (ICJ), in addition to addressing specific threats to peace and security.

In the most recent decade, the Security Council has still carried out its Charter-mandated duties, but its time has been increasingly spent on long-term monitoring of crisis areas, overseeing the work of subsidiary bodies, and providing a forum for UN members to define and act on common thematic interests. Subsidiary bodies include the UN CounterTerrorism Committee, the UN Compensation Commission, and sanctions monitoring bodies. Thematic interests include children, women, small arms, terrorism, rule of law, post-conflict peacebuilding, role of civil society in conflict prevention, security sector reform, illicit cross-border trafficking, piracy, and Ebola.

The UNSC has created new missions and bodies to handle these expanded responsibilities, including:

- international criminal tribunals for particular conflicts - the International Criminal Tribunal for the Former Yugoslavia (ICTY) and the International Criminal Tribunal for Rwanda (ICTR);

- monitoring bodies to verify disarmament as required by UNSC decisions, for example, in Iraq by the UN Special Commission (UNSCOM) 1991-98, and the UN Monitoring, Verification and Inspection Commission (UNMOVIC) from 2002-03;

- missions to implement peace agreements such as the 1999 UN Assistance Mission in East Timor (UNAMET);

- missions to provide humanitarian assistance and post-conflict reconstruction, such as the UN Assistance Mission in Afghanistan (UNAMA), set up in 2002, and the UN Assistance Mission for Iraq (UNAMI), authorized in 2003; ${ }^{15}$

- missions to investigate and fact-find;

- UN Special Representatives and Rapporteurs.

This list demonstrates the complex contemporary security environment in which the UNSC's responsibilities do not end with the cessation of hostilities but continue into economic and political reconstruction of a war-torn area. Missions may remain in existence for decades, making the Council responsible for the oversight of ongoing operations, but these operations are different from those originally envisaged in the Charter's Articles 43-48. Not all of the current operations involve 'military measures' (Article 45), and UN members are not required to contribute military forces or civilian personnel. The UNSC now depends on drawing together a variety of voluntary resources from member states to carry out 
its decisions. This leads to the possibility of individual states or a coalition providing inadequate resources to deal with a situation or, alternatively, undertaking stronger action than had been intended by the Council.

To the list of growing responsibilities undertaken by the UNSC is that of legislator. This occurred in the wake of the 9/11 terrorist attacks in New York in 2001. On 28 September 2001, the UNSC adopted Resolution 1373, directing all states under Chapter VII of the UN Charter to take certain actions against the financing of terrorism and terrorist activities. Drafted by the United States, Resolution 1373 'decides that all States shall' prevent and suppress the financing of terrorist acts; criminalize such activity; freeze such assets; and prohibit any person from making these funds available for terrorist activities. ${ }^{16}$ The language was sweeping and intrusive into the conduct of states within their own territories to regulate the actions even of their own nationals. By doing so, Resolution 1373 went beyond prior uses of Chapter VII - ordering actions of a limited scope and duration to discipline a particular country for UN Charter violations.

Resolution 1373, however, did not stop by directing states to take specific actions. It went on to institutionalize its response and established the Counter-Terrorism Committee (CTC) to monitor the implementation of the resolution. States were obliged to report actions taken to comply with Resolution 1373 within 90 days and on a periodic basis thereafter. More than 15 years after its creation, the CTC remains an institution with broad responsibility. The CTC is now aided by the Counter-Terrorism Committee Executive Directorate that 'carries out the policy decisions of the Committee, conducts expert assessments of each Member State and facilitates counter-terrorism technical assistance to countries'. ${ }^{17}$

This institutional structure placed the UNSC at the centre of antiterrorist activities, prompting action by other international organizations like the Inter-American Committee Against Terrorism (convened by the Organization of American States), the Organization for Security and Co-operation in Europe and the UN Office on Drugs and Crime. These actions have led to the conclusion that ' $[\mathrm{b}]$ eyond the functional objective of better coordinating counterterrorism action, the ability of the Council (through the CTC) to play the role of facilitator was unprecedented' ${ }^{18}$ Association with the CTC and the UNSC further provided teeth to other anti-terrorism efforts like those of the Financial Action Task Force.

This assertiveness to legislate the behaviour of all states in matters of counter-terrorism was possible because of the backing of the P5 and the forceful leadership of the United States. However, this sweeping action came at the price of broader support by the UN membership. Over time, 
this lack of support has been exacerbated by the burdensome reporting requirements imposed by Resolution 1373 that many states have found difficult to fulfil. The overall effectiveness of this effort to stem terrorism is also unclear. Nevertheless, the passage of Resolution 1373 demonstrated the power of the UNSC to direct action even within states should the P5 decide to do so. Such action could be taken to address crises created by drastic climate events and would be subject to little constraint beyond the ability of states to implement such legislation. Although the International Court of Justice might be able to exercise some form of judicial review over UNSC actions, it has thus far avoided doing so.

The seven decades of Council existence has seen a major shift from an emphasis on state security (the inviolability of borders) to human security (the inviolability of persons). As the 2004 Report of the SecretaryGeneral's High-level Panel on Threats, Challenges and Change noted:

The United Nations was created in 1945 above all else 'to save succeeding generations from the scourge of war' - to ensure that the horrors of the World Wars were never repeated. Sixty years later, we know all too well that the biggest security threats we face now, and in the decades ahead, go far beyond States waging aggressive war. They extend to poverty, infectious disease and environmental degradation; wars and violence within States; the spread and possible use of nuclear, radiological, chemical and biological weapons; terrorism; and transnational organized crime. The threats are from non-State actors as well as States, and to human security as well as State security. ${ }^{19}$

That security in both senses entailed action prior to the outbreak of conflict or war, to prevent that outbreak, if possible, was understood from the beginning. The first resolution passed by the UN General Assembly in January 1946 established a Commission to deal with the problems raised by atomic energy, directed to report to the Security Council. ${ }^{20}$

The dominance of a power structure dating from 1945 that no longer reflects today's international system calls into question the legitimacy of UNSC actions. The ability of the United Nations to carry out its responsibilities in the twenty-first century depends not only on effective UNSC decision-making, but also on the willingness and capacity to implement those decisions. This in turn requires the application of financial resources and other relevant assets by other UN members and their regional organizations, not just the P5 that the Charter envisioned as the likely providers of military assets in the context of 1945. States making such contributions want a voice in the disposition of their resources, whether military or civilian, particularly when their citizens are in harm's way, whether from natural causes or human conflict. Non-P5 UN members play a critical role in dealing with the issues 
identified by the High-level Panel on Threats, Challenges and Change and other emerging thematic concerns. Acknowledging that role means the ongoing need for the Security Council to develop its managerial and executive capacities.

The United Nations - and the Security Council as one of its principal organs - is called on to deliver collective action. As Vaughan Lowe has observed, "states therefore invest in this "security management institution" to coordinate their responses to security threats and capture the benefits of cooperation'. ${ }^{21}$ Such action ranges from a general debate to raise awareness of an issue, to gathering information, to taking military action against an aggressor state. UNSC decisions authorize member states to act, or the UN itself to act on behalf of its members, and UN members have political, legal and moral reasons to implement Council decisions. They provide legitimacy and order for conduct that would otherwise be unilateral and potentially disruptive to the international system.

Like all collective decision-making, UNSC decisions are necessarily negotiated outcomes and therefore may not provide as clear or as strong a response to a situation as circumstances warrant. Despite this, for 70 years the United Nations Security Council has been a venue where interested parties can make known their concerns to the global community. Throughout this process, the Security Council has adapted and 'undergone a process of change through practice' in response to the changed political environment in which it has had to work, the changing needs of the UN and its members, and the changing nature of global security. 22

\section{THE INTERTWINING OF LEGITIMACY AND EFFECTIVENESS QUESTIONS IN CONSIDERING WHETHER THE COUNCIL COULD OR SHOULD ACT ON CLIMATE CHANGE}

Despite the fact that the agenda of the Council - and the tools it has used to tackle the issues on its agenda - has evolved markedly, it is probably fair to say that the mainstream view at the time of producing this volume remains that climate change should be kept off the Council's agenda and climate change governance continues to be led by the UNFCCC under the auspices of the UN General Assembly (UNGA) rather than the Security Council. One of the main questions raised when this issue has 
been considered has been whether it would be legitimate for the Council to address this subject matter.

Legitimacy is not an esoteric question when it comes to the functioning of the Council but relates closely to that of effectiveness. For, in order for a Council decision to be effective, it needs to be broadly acceptable to the international community; if the decision were defied by most of the world, in practice what could the Council do about it? Despite the enormous formal powers of the Council, it is impractical for the Council to enforce compliance with all of its decisions: ultimately the Council relies on others perceiving its decisions to be sufficiently legitimate to comply with or ensure compliance with those decisions.

In the last 20 years, there has been considerable scholarly interest in the legitimacy of the UN Security Council, ${ }^{23}$ prompted in large part by a much more activist Council since the end of the Cold War. It is valuable, however, to distinguish the degree of legitimacy of the Council itself, from that of its specific decisions. Some Council actions, or actions taken in the name of the Council - and here the 2003 invasion of Iraq is an extreme example, are renowned for their perceived illegitimacy, whereas others, such as the establishment of a UN mission to tackle Ebola, have met with far less criticism, despite their pushing the boundaries of what had hitherto been thought to come within the Council's purview.

Experience has shown that there is likely to be a legitimacy deficit where the action appears to represent 'selective' as opposed to 'collective' security; that is, the action in question was taken to further the perceived national interests of the P5 (and it has generally been those of the United States) only, rather than for the greater good. Where a decision of the Council - Resolution 2177(2014) on Ebola, for example appears necessary, in terms of both the object of the resolution and tools used to address that scenario, the newness of the subject matter or tool deployed tends to have been far less debated. It is worth noting also that what is going to be perceived as necessary action by the Council will likely be at least partially related to what is happening elsewhere. If the Ebola crisis had been managed adequately through other institutional channels it is less likely that the Council would have stepped in.

Necessity as a proposed measure of the likely perceived legitimacy of a Council decision such as one in respect of climate change mitigation, adaptation or loss and damage derives from the origins of the enormous powers granted to the Council and to its permanent members. The 45 founding members of the UN did not simply accept the power asymmetries embodied in Council decision-making without a degree of protest. Yet the United States and USSR were not prepared to accept the enormous responsibilities they were to assume under the Charter without 
a guarantee that the P5 could have a final say over decisions. The P5 acquired both responsibilities and authority under the Charter. Yes, they were tasked with maintaining international peace and security, but no, they were not expected to carry that burden to the extent that it would risk their own peaceful relations amongst themselves, for this would have made the very existence of the Council self-defeating in respect of the maintenance of world peace. Like it or not, the bulk of states had little choice but to accept what was offered. And yet, through accepting the veto, the international community placed the onus on the P5 not to abuse that power by enforcing 'selective' as opposed to 'collective' security.

\section{THE UN SECURITY COUNCIL AND CLIMATE CHANGE - THE STORY SO FAR}

The legitimacy and effectiveness of the Security Council responding to climate change has been a subject of consideration in the United Nations since 2007.

\section{The 2007 Debate on the Inter-relationship of Energy, Climate and Security}

The Council first debated the inter-relationship of energy, climate and security in 2007 at the instigation of the United Kingdom. Fifty-five delegations participated in the debate, a number of which expressed views on the process of climate change or the links between climate change and security without opining on the appropriateness of Council involvement in this area. In broad terms, it was Europe and Pacific Island States that welcomed Council involvement, and China, developing countries and the Non-Aligned Movement ${ }^{24}$ that rejected the appropriateness of the Council examining the question. This underscores the important function of perceived necessity in determining Council institutional evolution, since it is the Small Island Developing States (SIDS) that face the most immediate existential threat and it is they who have been some of the strongest advocates of action by the Council. These states are also amongst the least empowered within the UNSC structure.

There were three broad lines of opposition raised in 2007. First was the assertion by India, echoed in the 2011 debate by China on behalf of developing countries, that the Security Council lacked the requisite expertise to address climate change. This is true, although it could equally be asserted that the Council always has to rely on expert advice and has formal mechanisms through which to obtain the information it 
requires. In any case, the IPCC exists to evaluate and report on scientific findings in this multifaceted area and could presumably assist the Council when and as requested.

The other two lines of opposition were inter-related and have continued to shape subsequent debate. First was that climate change is not a security issue at all; rather, it is a development issue and so by addressing climate change the Council was encroaching on the role of other UN bodies, particularly the General Assembly. Second, in contrast to the General Assembly, the Council is not universal and the status of its members is not equal. This means that it would be inappropriate for the Council to tackle climate change as it was agreed as long ago as the 1992 conclusion of the UNFCCC that climate change is to be addressed on the basis of equity and in accordance with the principle of CBDR and respective capabilities.

Most likely out of concern that the Council would 'take over' from the UNFCCC process with coercive measures, in 2007 states were reluctant even to accept that climate change was a matter of security, and those that did do so tended to refer only to 'security', as opposed to 'national', 'international', or 'human' security. Caution may have been exacerbated by the choice of language on the part of Britain, chair of the 2007 debate. Council President, Foreign Secretary Margaret Beckett declared that '[c]limate change is a security issue but it is not a matter of narrow national security - it has a new dimension. This is about our collective security in a fragile and increasingly interdependent world'. ${ }^{25}$ In lay terms, 'collective' may simply mean pertaining to us all, but in a more technical sense, 'collective security' represents the philosophical underpinning of the United Nations, particularly the Chapter VII powers of the Security Council. It would have been highly significant if the 2007 gathering had endorsed the proposition that climate change is a threat to collective security, because this could have been interpreted as providing a basis for the Council to respond with the full range of its powers, including Chapter VII coercive measures.

The 2007 debate thus revealed a range of positions on the question of whether the Council has a legitimate role to play in respect of climate and energy. The mainstream view was probably that this was an issue that belonged to the domain of the General Assembly and the UNFCCC; the notable exceptions were Europe and the SIDS for whom the urgency of action far outweighed the question of institutional boundary drawing. 


\section{The General Assembly and Climate Security, 2009}

A significant step towards opening up a window in which the Council could act occurred in June 2009 when, at the initiative of the Pacific SIDS, the General Assembly held a debate on climate change and its possible security implications. Importantly, through Resolution 63/281 (2009), the General Assembly '[i]nvite[d] the relevant organs of the United Nations, as appropriate and within their respective mandates, to intensify their efforts in considering and addressing climate change, including its possible security implications'.

This suggested less opposition to the Council playing some climate governance role than had seemed the case in 2007, albeit that the Assembly had thereby also confirmed that to be deemed legitimate by the broader UN membership that role should be restricted to the security dimensions of the issue. A role for the Council was to be accepted to the extent that it did not intrude on, or undermine, the work on climate change of other UN organs and subsidiary bodies. The UN General Assembly, representing the general UN membership, had thus signalled acceptance of some possible role for the UNSC, but the question remained, what role?

\section{The 2011 Debate of the UN Security Council}

The UN Security Council held its second debate on climate change in 2011, under the chair of Germany. The UN Secretary-General 'welcome[d] the fact that we have moved forward and are having the right debate today, about what the Council and all Member States can do to confront the double-barrelled challenge of climate change and international security'. ${ }^{26}$ There were, however, few concrete suggestions. There was some talk of mainstreaming climate change, in particular in respect of early warning assessments and conflict prevention. The Small Island Developing State of Nauru proposed the immediate appointment of a Special Representative on Climate and Security.

The Council issued a presidential statement expressing concern 'that possible adverse effects of climate change may, in the long run, aggravate certain existing threats to international peace and security' ${ }^{27}$ This was of considerable potential significance because the UN Security Council makes some decisions of a recommendatory nature but also has the power, under Chapter VII of the Charter, to require states to act as directed by the Council; for member states, such decisions override other legal obligations (UN Charter, Article 103). The necessary prerequisite to a Chapter VII decision is for the Council to identify a 'threat to the 
peace, breach of the peace, or act of aggression' emanating from climate change as per Article 39 of the Charter. Lawyers tend to endeavour to define legal limits on the exercise of the Council's powers, ${ }^{28}$ and yet, in practice, the most obvious limit to achieving any chapter VII resolution remains that of acquiring the requisite votes.

\section{Human Security and General Assembly Resolution 66/290 (2012)}

Interestingly, the EU delegate in 2011 referred to climate change not in terms of 'collective' or 'international' security but in the context of human security. The emergence into UN discourse of the concept of human security is usually dated from the Human Development Report 1994. In essence, the concept calls for a refocusing of security away from territorially defined states to the needs of the individual. The concept of human security met with a rather mixed reaction because of its radical potential: it was seen as a Western concept favouring the market economy and threatening the sovereignty and governing authority of countries in the South. ${ }^{29}$ In 2000, Secretary-General Kofi Annan declared that human security and national security rest on the same building blocks of freedom from want, freedom from fear, and the freedom of future generations to inherit a healthy environment, ${ }^{30}$ apparently conceptualizing them as parallel tracks. The United Nations Development Plan (UNDP) subsequently asserted in 2009 that 'state security is necessary for individual human security', ${ }^{31}$ appearing to suggest that the security of the state is the more fundamental.

The question remained, however, of whether a threat to 'human security' meets the threshold standard of a threat to 'international peace and security' as per Article 39 of the Charter - of considerable significance if climate change is accepted to threaten human security. This was clarified in 2012. General Assembly Resolution 66/290 (2012) specified that human security does not entail the threat or the use of force or coercive measures. Human security 'must be implemented with full respect for ... the sovereignty of States, territorial integrity and noninterference in matters that are essentially within the domestic jurisdiction of States'. This suggests that broad agreement that the threat posed by climate change is one to human as opposed to international or collective security would be unlikely to be perceived as providing legitimation for coercive measures by the Council but would help clear the way for the Council to directly address climate change through means short of Chapter VII - for example, through integrating climate adaptation considerations into peace building. 
This would still stop short of embodying in any far-reaching way the CBDR principle, another potential stumbling block to acceptance of a climate role for the Council, particularly by China. The prospect of the Council sidelining equity considerations is likely the most significant impediment to the perceived legitimacy of the Council tackling climate change and energy. As we have seen, the Council was established to ensure security more so than justice, although it is worth noting that Charter references to human rights reflect recognition that security ultimately requires respect for the inherent dignity of all people. ${ }^{32}$ To be fully accepted as an appropriate body in this space, the Council will likely require not only a sense of urgency for an overall coordinating body with coercive powers at its disposal should they be required, but also evidence sufficient to convince sceptics that the Council would use those powers for the greater good. The apparent decline in support for the concept of 'Responsibility to Protect' (R2P) following military intervention in Libya allegedly exceeding its mandate is salutary in this regard..$^{33}$

\section{3, 2015, 2016 and 2017 Debates}

In 2013, the UK and Pakistan co-chaired an Arria-formula meeting ${ }^{34}$ on the 'security dimensions of climate change' and in 2015 Spain and Malaysia co-hosted an Arria-formula meeting on the role of climate change as a threat multiplier for global security. Another Arria-formula meeting in 2016, led by Senegal, which discussed 'water, peace and security' included considerable emphasis on climate security. Egypt and Spain in 2016 convened a UNSC information session on challenges to the Sahel region with a special focus on climate. Then in Resolution 2349 of 31 March 2017 the Council recognized in a substantive provision the adverse effects on regional stability in the Lake Chad Basin of climate change and ecological changes, 'including through water scarcity, drought, desertification, land degradation, and food insecurity, and emphasize[d] the need for adequate risk assessments and risk management strategies by governments and the United Nations relating to these factors'. ${ }^{35}$ It is probably fair to conclude, however, that despite intermittent attention being given to the question of a climate change role for the UNSC, there has still been very little discussion of just what the Council could or should do if it were to act.

On the other hand, it could be said that the Council has in fact already responded to climate change, albeit by default. Although the Council has not passed any resolutions explicitly addressing climate change mitigation or adaptation, it has already responded to crises - the most 
prominent of which has probably been Darfur, but others include Ebola and the Sahel region crisis, which are recognized to have been exacerbated by climate change. This suggests the importance, in debating a climate change role for the UN Security Council, of distinguishing between an explicit role, in which climate change is mentioned by name, and a Council response to a crisis that presents in a more traditional or human security form, but which has almost certainly been exacerbated by climate change (see Table 1.1). ${ }^{36}$

\section{REVERSING THE BURDEN OF PROOF IN RESPECT OF LEGITIMACY}

Whereas discussion to date has been couched largely in terms of whether it would be legitimate for the Council to address climate change, scientific evidence suggests that at some point discourse may well shift to the question of how the Council can legitimately avoid making any serious contribution to climate change adaptation, or even mitigation. Given the primary responsibility of the Council for the maintenance of international peace and security, it may just be that the effects of climate change become so overwhelming and widespread that the Security Council simply cannot be left out of global efforts. Indeed, even in 2011 the US Representative to the United Nations suggested that responding to climate change was a 'core responsibility' of the Council:

We have dozens of countries represented in this body and in this very Chamber whose very existence is threatened. They have asked the Council to demonstrate our understanding that their security is profoundly threatened. Instead, because of the refusal of a few to accept our responsibility, by its silence the Council is saying in effect 'tough luck'. That is more than disappointing; it is pathetic, short-sighted and, frankly, a dereliction of duty. ${ }^{37}$

The IPCC Fifth Assessment Report noted that a number of components of the climate system, including the Atlantic Meridional Overturning Circulation $^{38}$ and Arctic sea ice, have been identified as potentially exhibiting threshold behaviour. Crossing specific thresholds could lead to abrupt or irreversible change in certain components of the system or the global climate system as a whole. ${ }^{39}$ Other potential 'tipping elements' include dieback of the Amazon rainforest and shift of the West African monsoon. ${ }^{40}$ The consequences of passing a tipping point may be obvious immediately, or may play out over years or decades, long after the opportunity to take effective remedial action has passed. 
Some information regarding potential consequences of passing such tipping points is already available, ${ }^{41}$ and considerable work is underway to better understand such non-linearities and the relationship both between tipping elements and extreme weather characteristics, and between various tipping elements themselves. ${ }^{42}$ Thus, for example, the northern jet stream and Arctic sea ice appear to be linked via the decrease in wintertime sea ice, leading to a shift in wind patterns. ${ }^{43}$ Non-linearity within a system often arises because of positive feedbacks in their internal dynamics. ${ }^{44}$ There is particular concern that reaching one tipping point increases the risk of reaching another, with a domino effect. ${ }^{45}$

In 2013, the IPCC found there to be generally low confidence and little consensus on the likelihood of passing major tipping points this century, ${ }^{46}$ but this naturally depends on a number of factors, including the extent to which mitigation policies are effective. It would seem that at least one major tipping point will be passed if and when we reach a $>4{ }^{\circ} \mathrm{C}$ warmer world. ${ }^{47}$ Post-Paris projections of future temperature rises depend in large part on how compliant states are with their nationally determined contributions and whether or not ambition is scaled up. Fawcett et al. have determined that, if ambition is successfully scaled up after 2030 , the probability of limiting warming to $2^{\circ} \mathrm{C}$ increases to some 30 per cent. ${ }^{48}$

Meanwhile, climate change has already led to an increase in the frequency and intensity of daily temperature extremes and to widespread intensification of daily precipitation extremes. ${ }^{49}$ Scientists have demonstrated that climate change is already causing an expansion of subtropical drylands and widespread loss of mountain snow packs and glaciers, meaning that the fact that several large-scale tipping points in the global climate system could be passed this century needs to be understood in the context that on smaller scales there are many potential ecosystem tipping points. ${ }^{50}$ Furthermore, although the science of attributing specific extreme weather events to climate change has a considerable way to go, tipping points need to be understood as one of a larger category of 'environmental shocks' that societies are likely to face in coming decades; others include extreme events such as typhoons, as well as abrupt swings, for example an El Niño event. ${ }^{51}$

Physical effects of climate change pose major challenges to vital transport, water and energy infrastructure. ${ }^{52}$ Environmental shocks impact social systems, and there have recently been investigations into the possibility of climatically sensitive social tipping points. ${ }^{53}$ In the same way that it would appear that climate change is usually one in a complex mix of factors leading to the outbreak of conflict, ${ }^{54}$ environmental shocks, their social impacts, and recognition of the inadequacies 
of current governance responses to climate change, could potentially lead to dramatic shifts in governance approach. Historically, at times of severe security emergency, even in democracies, the tendency is towards more authoritarian rule. And at a global level, the 'go-to' institution when there are really serious global security issues, including, increasingly ones of a human security nature - is the UN Security Council. This suggests that in circumstances of dire security threat or crisis, potentially triggered by a climate 'tipping point', or by a close coincidence of multiple environmental, economic, and social 'shocks', there may well be greater appetite to accept far less democratic modes of global climate governance.

\section{THE CONTRIBUTIONS IN THIS VOLUME}

This volume seeks to focus on 'positive', constructive, contributions that the Council could make to the collective response to climate change. The question of whether it would be politically feasible for the Council to act certainly remains central, but as noted in the above discussion, the Council is already responding by default to climate change, and it will likely be more extensively engaged in the future as the effects of climate change are more widely felt. The exact trigger for such engagement may not yet be known, but given the prospects for future disasters, it is conceivable that a confluence of disasters and their implications for international peace and security may prompt much more explicit Council engagement than hitherto. International environmental law has throughout its history been profoundly shaped by disasters, and it has become increasingly difficult to distinguish natural from human-induced disasters. ${ }^{55}$ Reflection on operational precedents and models of how the Council might best respond in the face of such a crisis or event is an important step towards creating appropriate governance and management structures.

Indeed, it is worth noting that even since the idea for this project began to take shape, the questions we are posing have already become less far-fetched. The Syrian experience has underscored the complex interplay of causal factors that impact conflict $^{56}$ the sheer scale on which displacement can take place and its potential impact on the developed, as well as the developing world. Disaster law may be still in its formative stage, ${ }^{57}$ but is attracting increasing attention. And the nature of the Paris Agreement has made it 'inevitable' that courts will have a significant role to play in elaborating on the detail of climate-related obligations and commitments. ${ }^{58}$ This may be via existing domestic and international courts, but raises the potential need for a dedicated climate court. 
Andreopoulos has referred to two related perils of broadening the Council's agenda: 'the image of enlightened despotism at best and sheer puppetry at worst'. ${ }^{59}$ Arguably, if the Council were to avoid accusations of puppetry in the sense of selective security it could not but avoid some degree of enlightened despotism in the sense that its very strength as a go-to body is its small membership. On the other hand, this does not mean that Council involvement need ipso facto equate with punitive intervention by a US- or other P5-led international coalition against a country perceived as threatening P5 interests. Mention of Security Council action tends to elicit an assumption that the Council would be taking punitive measures against those with whom the P5 is out of favour, but it is a premise of this volume that physical shocks and tipping points may well be the prelude to governance shocks, and that this therefore need not necessarily be the case.

It may be helpful to recall that the UNSC is empowered to authorize a whole range of actions of both a recommendatory and compulsory nature, ranging from fact-finding and monitoring to operations of varying sizes and complexity including armed intervention.

Table 1.1 maps in broad terms the range of policy options available to the Council, from rejection of any involvement with the issue to drawing on its compulsory powers to essentially become the focal point in the global governance response. This chapter has suggested that, even though the Council may continue merely to debate the subject and take action 'by default', it is also feasible that the Council may be compelled of necessity to take explicit action. There may well be actions that the Council could usefully begin to take to be better equipped to move more explicitly into this policy arena.

If it were to do so, this may mean drawing on, and adapting, its existing repertory of tools or developing new tools for the specific task at hand. To investigate the possibilities, the editors invited a group of leading and newer scholars to explore in greater depth the themes raised in this opening chapter. Several chapters address the possibility of Council action: Penny considers whether action would be legally justifiable in Chapter 2; Binder and Heupel whether action would be considered legitimate in Chapter 10; Far and Youngs look at the development focus of the EU's approach to climate security in Chapter 8; and Scott the attitude of the P5 in Chapter 11. In Chapter 5, Mégret and Mayer question whether climate migration may necessitate a Council response, while $\mathrm{Ku}$ looks at whether the Council may need to step up to the role of global crisis coordinating body in Chapter 9. 


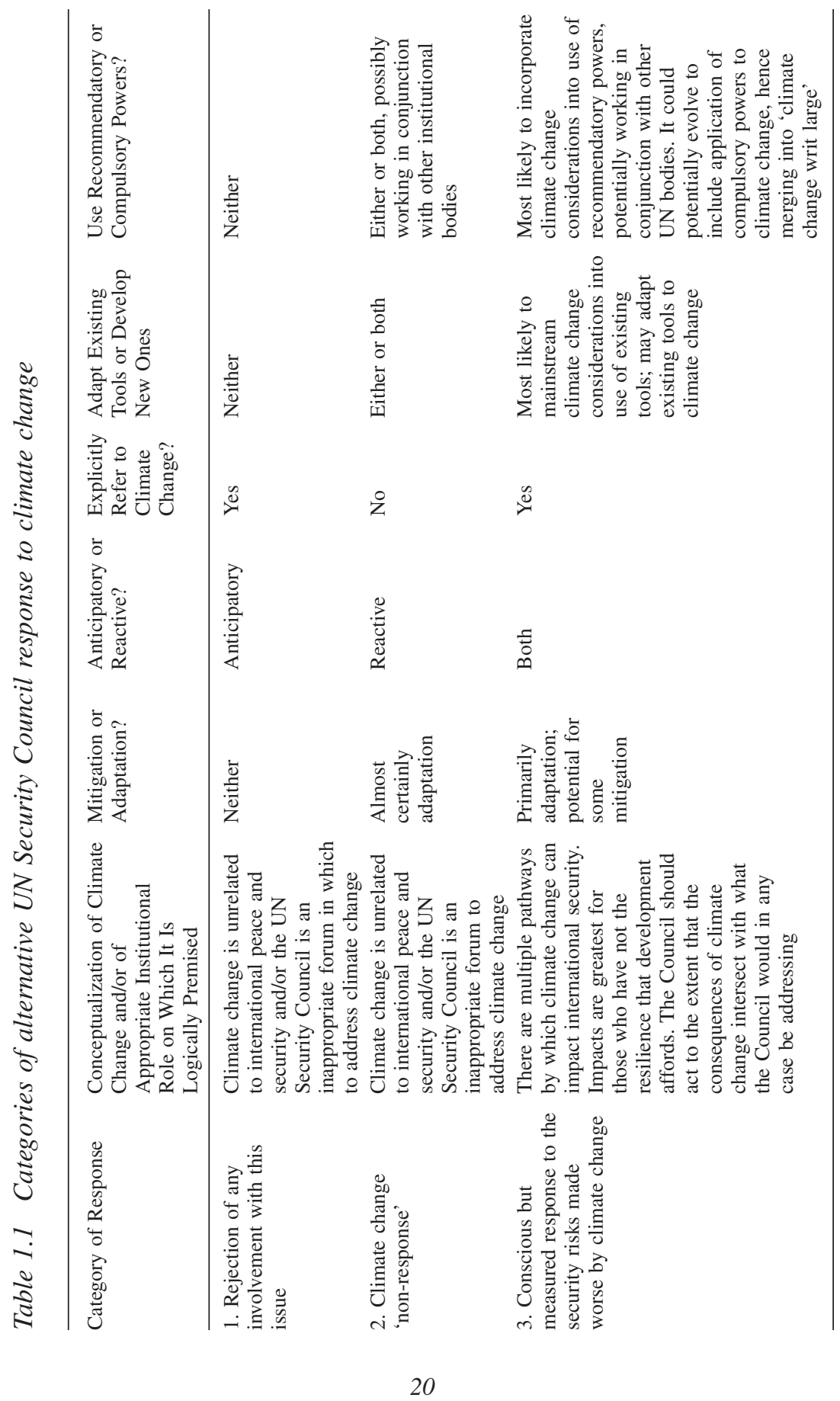




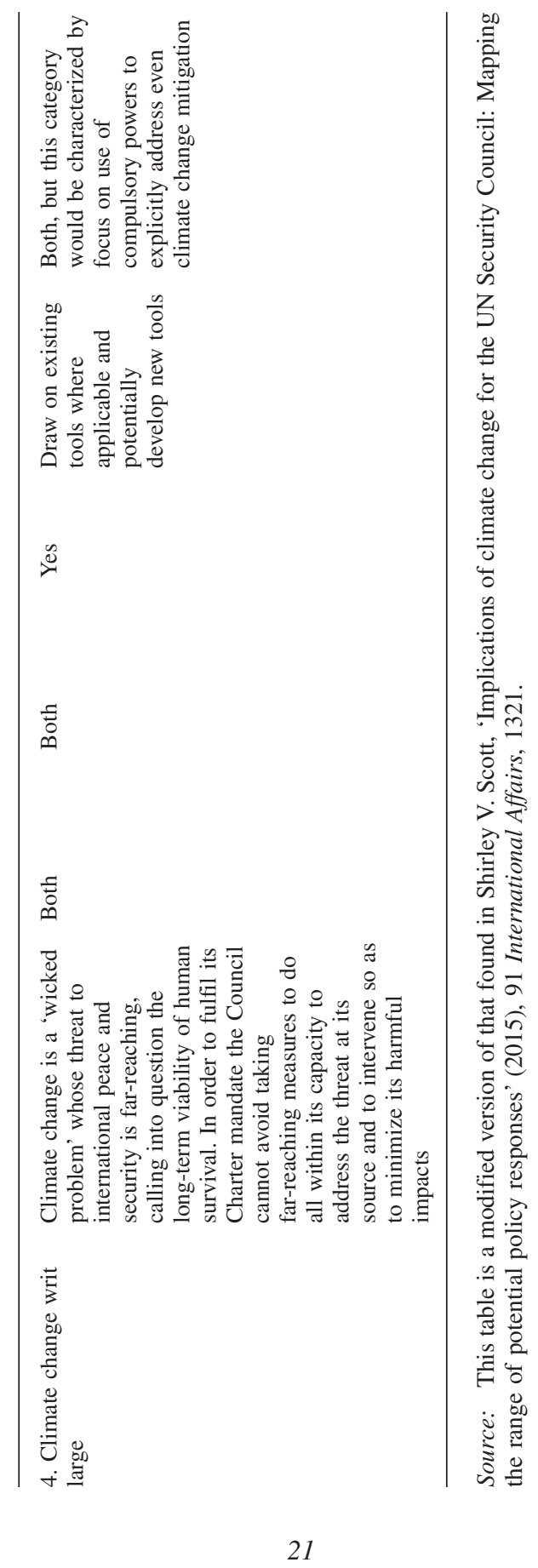

Shirley V. Scott and Charlotte Ku - 9781785364648 
The majority of the chapters consider the utility of the Council adapting its existing tools to the task. In Chapter 3, Sindico and Orme look at the applicability of sanctions and economic measures, Scott, Keenan and $\mathrm{Ku}$ at what might be learnt from the Council's previous establishment of international criminal tribunals in Chapter 4; and Boyle, Hartmann and Savaresi at the potential for the Council to make constructive use of its legislative functions in Chapter 6. Diehl, in Chapter 7, considers whether climate change adaptation might usefully be incorporated into peace missions.

The editors return in the concluding chapter to evaluate lessons learned regarding what the Council could most usefully do were it to take up the mantle and prepare for the future that scientists believe human civilization may well encounter.

\section{NOTES}

1. Daniel Bodansky, 'The history of the global climate change regime', in Urs Luterbacher and Detlef F. Sprinz (eds), International Relations and Global Climate Change (MIT Press, 2001), 28.

2. 'The changing atmosphere: Implications for global security' (Conference Statement, Toronto, 27-30 June, 1988), accessed 19 October 2017 at http://www.academia.edu/ 4043227/The_Changing_Atmosphere_Implications_for_Global_Security_Conference_ Statement_1988.

3. See, inter alia, Alan H. Lockwood, Heat Advisory. Protecting Health on a Warming Planet (MIT Press, 2016); Walter Kälin and Hannah Entwisle Chapuisat, 'Displacement in the context of disasters and adverse effects of climate change', in Susan C. Breau and Katja L.H. Samuel (eds), Research Handbook on Disasters and International Law (Edward Elgar Publishing, 2016).

4. Caitlin Werrell and Francesco Femia, Centre for Climate and Security, 'Intelligence Director on climate change as "underlying meta-driver of unpredictable instability", accessed 9 September 2016 at https://climateandsecurity.org/2016/09/09/intelligencedirector-on-climate-as-underlying-meta-driver-of-unpredictable-instability/.

5. UNGA (United Nations General Assembly) Res. 43(53) (6 December 1988), UN Doc. A/RES/43/53.

6. Robert Stavins and others, 'International cooperation: Agreements and instruments', in Robert Stavins and others (eds), Climate Change 2014: Mitigation of Climate Change. Contribution of Working Group III to the Fifth Assessment Report of the Intergovernmental Panel on Climate Change (Cambridge University Press, 2014), 1012.

7. UNSC Res. 2349 (31 March 2017), S/RES/2349.

8. Edward C. Luck, 'A council for all seasons: The creation of the Security Council and its relevance today', in Vaughan Lowe and others (eds), The United Nations Security Council and War: The Evolution of Thought and Practice since 1945 (Oxford University Press, 2008), 63.

9. J.P.D. Dunbabin, 'Council non-involvement in wars', in Vaughan Lowe and others (eds), The United Nations Security Council and War: The Evolution of Thought and Practice since 1945 (Oxford University Press, 2008), 508.

10. Vaughan Lowe and others, 'Introduction', in Vaughan Lowe and others (eds), The United Nations Security Council and War: The Evolution of Thought and Practice since 1945 (Oxford University Press, 2008), 25. 
11. See United Nations Peacekeeping, 'Peacekeeping fact sheet' (as of 30 April 2016), accessed 30 July 2016 at http://www.un.org/en/peacekeeping/resources/statistics/factsheet/ shtml.

12. See United Nations Peacekeeping, 'Financing peacekeeping', accessed 30 July 2016 at http://www.un.org/en/peacekeeping/operations/financing.shtml.

13. Charlotte $\mathrm{Ku}$ and Harold K. Jacobson, 'Introduction: Broaching the issues', in Charlotte $\mathrm{Ku}$ and Harold K. Jacobson (eds), Democratic Accountability and the Use of Force in International Law (Cambridge University Press, 2002), 24.

14. Mats Berdal, 'The Council and peacekeeping', in Vaughan Lowe and others (eds), The United Nations Security Council and War: The Evolution of Thought and Practice since 1945 (Oxford University Press, 2008), 191.

15. Lowe and others (n. 10), 23-4.

16. UNSC Res. 1373 (28 September 2001), UN Doc. S/RES/1373, 2.

17. See information on the UN Security Council Counter-Terrorism Committee at https:// www.un.org/sc/ctc/.

18. Peter Romaniuk, 'Responding to terrorism', in Sebastian von Einsiedel and others (eds), The UN Security Council in the 21st Century (Lynne Rienner Publishers, 2016), 284.

19. High-level Panel on Threats, Challenges and Change, A More Secure World: Our Shared Responsibility (United Nations, 2004), 1.

20. UNGA Res. 1(I) (24 January 1946).

21. Lowe and others (n. 10), 29.

22. Ibid., 23.

23. See, inter alia, Martin Binder and Monika Heupel, 'The legitimacy of the UN Security Council: Evidence from recent General Assembly debates' (2015), 59 International Studies Quarterly 2, 238; Ian Hurd, After Anarchy: Legitimacy and Power in the United Nations Security Council (Princeton University Press, 2007).

24. An international organization of countries who do not want to be officially aligned with or against any major power bloc. In 2017, the movement had 125 members. See Non-Aligned Movement, Centre for South-South Technical Cooperation website at http://csstc.org/.

25. Andrew Clark, 'Climate change threatens security, UK tells UN', The Guardian (18 April 2007).

26. UNSC Provisional Verbatim Record (20 July 2011), UN Doc. S/PV/6587, 2.

27. UNSC Presidential Statement (20 July 2011), UN Doc. S/PRST/2011/15.

28. See, inter alia, Rain Liivoja, 'The scope of the supremacy clause of the United Nations Charter' (2008), 57 International \& Comparative Law Quarterly 3, 583; and Hitoshi Nasu, 'Chapter VII powers and the rule of law: The jurisdictional basis' (2007), 26 Australian Yearbook of International Law 87.

29. Jean-Philippe Thérien, 'Human security: The making of a UN ideology' (2012), 26 Global Society 2, 191, 213.

30. UN press release, 'Secretary-General salutes international workshop on human security in Mongolia' (Ulaanbaatar, 8-10 May 2000), accessed 30 July 2016 at http://www.un.org/ News/Press/docs/2000/20000508.sgsm7382.doc.html.

31. UNDP, Arab Development Report 2009: Challenges to Human Security in the Arab Countries (United Nations, 2009), 189.

32. Shirley V. Scott, International Law in World Politics. An Introduction, Third Edition (Lynne Rienner, 2017), 239.

33. See, inter alia, Gareth Evans, 'R2P down but not out after Libya and Syria' Open Democracy (9 September 2013), accessed 19 October 2017 at https://www.open democracy.net/openglobalrights/gareth-evans/r2p-down-but-not-out-after-libya-and-syria; and Christopher Hobson, 'Responding to failure: The Responsibility to Protect after Libya' (2016), 44 Millennium: Journal of International Studies 3, 433.

34. 'Informal, confidential gatherings that enable Security Council members to have a frank and private exchange of views, within a flexible procedural framework', UNSC, Working Methods Handbook, accessed 17 October at http://www.un.org/en/sc/about/methods/ bgarriaformula.shtml. 
35. UNSC Res. 2349 (31 March 2017), UN Doc. S/RES/2349, 7.

36. Shirley V. Scott, 'Implications of climate change for the UN Security Council: Mapping the range of potential policy responses' (2015), 91 International Affairs 6, 1317, 1328.

37. UNSC (n. 26), 7.

38. A major current in the Atlantic ocean, an important component of the climate system.

39. Thomas F. Stocker and others, 'Technical summary', in Thomas F. Stocker and others (eds), Climate Change 2013: The Physical Science Basis. Contribution of Working Group I to the Fifth Assessment Report of the Intergovernmental Panel on Climate Change (Cambridge University Press, 2013), 70.

40. Timothy M. Lenton, 'Early warning of climate tipping points' (2011), 1 Nature Climate Change 3, 201.

41. Stocker and others (n. 39), 70.

42. Hans Joachim Schellnhuber and Maria A. Martin, 'Climate-system tipping points and extreme weather events', in Hans Joachim Schellnhuber and Maria A. Martin (eds), Sustainable Humanity, Sustainable Nature: Our Responsibility (Pontifical Academy of Social Sciences, Vatican City, 2014), accessed 30 July 2016 at http://www.casinapioiv.va/ content/dam/accademia/pdf/es41/es41-schellnhuber.pdf.

43. Jennifer A. Francis and Stephen J. Vavrus, 'Evidence linking Arctic amplification to extreme weather in mid-latitudes' (2012), 39 Geophysical Research Letters 6, 1.

44. Timothy M. Lenton, 'What early warning systems are there for environmental shocks?' (2013), 27 Environmental Science \& Policy S1, S60.

45. Derek Lemoine and Christian P. Traeger, 'Economics of tipping the climate dominoes' (2016), 6 Nature Climate Change 5, 514.

46. Stocker and others (n. 39), 70.

47. Lenton (n. 40), S71.

48. Allen A. Fawcett and others, 'Can Paris pledges avert severe climate change?' (2015), 350 Science, 1168.

49. Peter Stott, 'How climate change affects extreme weather events' (2016), 352 Science $6265,1517$.

50. Lenton (n. 44), S71.

51. Ibid., S62.

52. W. Neil Adger and others, 'Human security', in Christopher B. Field and others (eds), Climate Change 2014: Impacts, Adaptation, and Vulnerability. Part A: Global and Sectoral Aspects. Contribution of Working Group II to the Fifth Assessment Report of the Intergovernmental Panel on Climate Change (Cambridge University Press, 2014).

53. Robert E. Kopp and others, 'Tipping elements and climate-economic shocks: Pathways toward integrated assessment' (2016), 4 Earth's Future 8, 346, accessed 30 July 2016 at http://onlinelibrary.wiley.com/doi/10.1002/2016EF000362/full.

54. Adger and others (n. 52).

55. Tim Stephens, 'Disasters, international environmental law and the Anthropocene', in Susan C. Breau and Katja L.H. Samuel (eds), Research Handbook on Disasters and International Law (Edward Elgar Publishing, 2016), 153.

56. Peter H. Gleick, 'Water, drought, climate change, and conflict in Syria' (2014), 6 Weather, Climate, and Society 3, 331.

57. Susan C. Breau and Katja L.H. Samuel, 'Preface' in Research Handbook on Disasters and International Law (Edward Elgar Publishing, 2016), xiii.

58. Philippe Sands, 'Climate change and the rule of law: Adjudicating the future in international law' (2016), 28 Journal of Environmental Law 1, 19. See also Brian J. Preston, 'The contribution of the courts in tackling climate change' (2016), 28 Journal of Environmental Law 1, 11.

59. George J. Andreopoulos, 'The challenge and perils of normative overstretch', in Bruce Cronin and Ian Hurd (eds), The UN Security Council and the Politics of International Authority (Routledge, 2008), 124. 